\title{
Phthiraptera (Arthropoda, Insecta) in Gallus gallus from isolated and mixed backyard rearing systems
}

Phthiraptera (Arthropoda, Insecta) em Gallus gallus de criaçóes de fundo de quintal isoladas e mistas

Ana Clara Gomes dos Santos ${ }^{1 *}$; Albério Lopes Rodrigues ${ }^{3}$; Sandra Batista dos Santos²;

Roberto César Araújo Lima ${ }^{3}$; Rita de Maria Seabra Nogueira de Candanedo Guerra ${ }^{1}$

${ }^{1}$ Laboratório de Parasitologia, Universidade Estadual do Maranhão - UEMA

${ }^{2}$ Centro Universitário de Desenvolvimento do Centro-Oeste - UNIDESC

${ }^{3}$ Departamento de Agropecuária, Centro de Formação de Tecnólogos, Universidade Federal da Paraíba - UFPB

Received June 24, 2010

Accepted October 8, 2010

\begin{abstract}
The objectives were to identify the species of chewing lice (Mallophaga) at different body sites in chickens (Gallus gallus), in isolated and mixed rearing systems, and to determine the dynamics and structure of the louse populations collected. The prevalences were 100 and 35\% for chickens in the isolated and mixed systems, respectively. The species recorded were: Menopon gallinae, Menacanthus stramineus, Goniodes gigas, Goniocotes gallinae and Lipeurus caponis. The chickens in the isolated system presented more lice than did the ones in the mixed system. The most prevalent species were M. gallinae (30.58 and 62.31\%) and L. caponis (29.12 and 14.49\%), in the isolated and mixed systems, respectively. The preferential sites of parasitism were the dorsum, venter and wings among the chickens in the isolated system, while among the ones in the mixed system, the preferential sites were the dorsum and venter. The mean intensity of infestation in the isolated system was 111.4 for males and 19.1 for females, while in the mixed system it was 80 for males and 6.75 for females. The amplitudes of the infestation were 1-226 for males and 1-22 for females in the isolated system, while in the mixed system, the amplitudes were 1-111 and 1-8, respectively. It can be concluded that chickens reared in the isolated system harbor a greater number of lice than do chickens in the mixed system. However, the kind of rearing system does not prevent louse infestations.
\end{abstract}

Keywords: Gallus gallus, Phthiraptera.

\section{Resumo}

Objetivou-se identificar as espécies de malófagos em diferentes regiōes do corpo de Gallus gallus, sob os sistemas de criação isolado e misto e determinar a dinâmica e estrutura da população. A prevalência de parasitismo foi de 100 e 35\% para as aves no sistema de criação isolado e misto, respectivamente. As espécies identificadas foram: Menopon gallinae, Menacanthus stramineus, Goniodes gigas, Goniocotes gallinae e Lipeurus caponis. As aves mantidas isoladas apresentaram maior parasitismo do que aquelas sob o sistema misto de criação. As espécies mais prevalentes foram M. gallinae (30,58 e 62,31\%) e L. caponis (29,12 e 14,49\%), nos sistemas isolado e misto, respectivamente. As regióes do corpo preferenciais dos malófagos foram dorso, ventre e asa para as aves do sistema isolado; e o dorso e ventre para as do sistema misto. Para as aves do sistema isolado, a intensidade média de infestação para os machos foi de 111,4 e para as fêmeas foi de 19,1. E, para o sistema misto foi de 80 e 6,75 para machos e fêmeas, respectivamente. A amplitude de infestaçáo variou de 1-226 e 1-22 para machos e fêmeas, respectivamente (sistema isolado); enquanto para o sistema misto foi de 1-111 e 1-8, para machos e fêmeas, respectivamente. Conclui-se que as aves de fundo de quintal, criadas sob o sistema isolado de criação, apresentam maior infestação por malófagos do que aquelas criadas com outras espécies de aves, embora o sistema de criação não isente as aves do parasitismo.

Palavras-chave: Gallus gallus, Phthiraptera. 


\section{Introduction}

Poultry rearing is a profitable activity that provides an excellent protein source for consumers. Today, it is seen that there is a consumer market for products with better health attributes, and backyard chicken rearing forms part of this scenario. However, even though chickens are easy to manage, they are not free from infections and/or parasitic infestations.

Among the ectoparasites that can infest poultry, biting/chewing lice (Phthiraptera; Mallophaga) stand out, especially because of their diversity and high capacity for infesting their hosts. Chewing lice that infest poultry feed on sloughed tissue from the skin and feathers, and on sebaceous secretions (FIGUEIREDO et al., 1993). Infestations give rise to restlessness, self-mutilation together with feather loss, thermal imbalance and sleeplessness among poultry. Furthermore, they affect feeding, which gives rise to weight loss and decreased egg production (PANDA; AHLUWALIA, 1983; GLESS; RAUN, 1959; OLIVEIRA et al., 1999; PINTO et al., 2001).

According to Emerson (1956), domestic hens (Gallus gallus) are parasitized by a greater variety of louse species than any other bird species. From the literature, the following species are known to parasitize domestic hens: Menopon gallinae L., Menacanthus pallidulus Neumann, Menacanthus cornutus Schommer, Menacanthus stramineus Nitzsch, Goniocotes gallinae De Geer, Goniodes dissimilis Denny, Goniodes gigas Taschenberg, Lipeurus caponis L. and Cuclotogaster heterographus Nitzsch (EMERSON, 1956).

Regarding the site of parasitism, Ash (1960) stated that each louse species is located in a well-defined body zone or niche in its host.

Knowledge of louse species and their locations in their hosts' bodies is of fundamental importance for indicating preventive and therapeutic measures to maintain the health and productivity of the breeding stock.

The present study had the aims of identifying louse species; determining the preferential regions for parasitism on the bodies of backyard chickens, according to the rearing system used (isolated or mixed); and investigating the structure and dynamics of the population collected.

\section{Material and Methods}

The material was collected from backyard chicken rearing systems on the periphery of the city of Patos, State of Paraíba, which is located at the coordinates $7^{\circ} 01^{\prime} 37.78^{\prime \prime} \mathrm{S}$ and $37^{\circ} 16^{\prime} 39.40^{\prime \prime} \mathrm{W}$, in the mesoregion of the backlands of Paraíba. This region is characterized by a semi-arid climate and scrub vegetation, with a mean annual temperature of $37.9^{\circ} \mathrm{C}$ (maximum) and $24.6{ }^{\circ} \mathrm{C}$ (minimum) and mean rainfall of $364.33 \mathrm{~mm}$, occurring as rare and irregular showers (IBGE, 2002).

Forty hens were examined: 20 that were kept in a system of isolated rearing (i.e. just one poultry species present) and 20 that were kept in a mixed system (i.e. more than one poultry species cohabiting in the same space). The samples were collected from two properties: one with isolated rearing, consisting solely of backyard chickens; and the other with rearing not only of backyard chickens but also of farmyard ducks, garganey ducks, turkeys and guineafowl. In both systems, the management was the same: during the day, the hens were let loose and at night they were gathered into a hencoop constructed of sticks.

The hens were inspected visually and were selected randomly, independent of their physical appearance and without considering their breed (if any). In this study, the following regions of the body were taken into consideration: head, neck, dorsum, venter, cloaca and wings.

The samples were collected manually, by removing tufts from feathers in each region. These were then packed in glass vials containing $70 \%$ alcohol; identified according to the region of the body, sex and rearing system; and sent to the Veterinary Parasitology Laboratory, Centro de Saúde e Tecnologia Rural (CSTR), Universidade Federal de Campina Grande (UFCG), Patos Campus, Paraíba, for louse identification.

The louse specimens were screened according to sex and biological development stage (egg, nymph or adult), with the aid of entomological probes and a stereomicroscope, and were mounted on slides with coverslips in accordance with the technique described by Pinto (1938). The identification key produced by Tuff (1977) was used.

The data were assessed using analysis of variance (ANOVA), followed by Tukey's test at probability levels of 5 and $1 \%$, with comparisons of the means between the louse species found in each rearing system, with the aid of the Instat v. 2.05a computer software (1990-1994).

To study the population structure after species identification, the lice were quantified according to development stages (eggs, nymphs, male adults and female adults). These data were analyzed in accordance with Silveira Neto et al. (1976).

\section{Results and Discussion}

The species identified in the different regions of the hosts' bodies in the two rearing systems were: Menopon gallinae, Menacanthus stramineus, Goniodes gigas, Goniocotes gallinae and Lipeurus caponis. Species of the suborder Ischnocera predominated in relation to the suborder Amblycera, thus differing from the observations of Ferrero et al. (2004) and agreeing with Figueiredo et al. (1993) and Silva (2002). The prevalence of infestation observed was $100 \%$ among the hens reared in the isolated system and 35\% in the mixed system.

The mean levels of parasitism among the hens reared in the isolated system are shown in Table 1 . The species $M$. gallinae differed significantly from $M$. stramineus, and the latter differed from L. caponis ( $\mathrm{P}<0.05)$. However, in the mixed rearing system, only $M$. gallinae presented a significant difference, compared with the other species $(\mathrm{P}<0.01)$.

The hens that were samples presented simultaneous parasitism by more than one louse species. This has already been described in the literature (EMERSON, 1956; UGOCHUKWU; OMIJE, 1986; FIGUEIREDO et al., 1993; PINTO et al., 2001; FERRERO et al., 2004; GUERRA et al., 2008).

According to Figueiredo et al. (1993), a variety of louse species infest domestic poultry. They highlighted $M$. gallinae, M. stramineus, G. gigas, G. gallinae and L. caponis, which were 
all found in the present study. On the other hand, despite observations of parasitism due to $M$. contortus in farmyard hens in the state of Rio Grande do Sul (Oliveira and Ribeiro, 1990) and $G$. dissimilis in backyard hens in the states of São Paulo and Rio de Janeiro (PINTO et al., 2001) and on the island of São Luis, State of Maranhão (GUERRA et al., 2008), these species were not identified in the present study. Although the louse fauna is known, there are differences in the species that affect poultry in different geographic areas. Climatic conditions may influence species adaptation. Guerra et al. (2008) observed statistical differences in some louse species in poultry on the island of São Luis, between the dry and wet seasons.

According to Emerson (1956) and Emerson (1962), the species M. stramineus is typical of turkeys (Meleagris gallopavo),

Table 1. Numbers of specimens, prevalence, mean and standard deviation among louse species collected from (Gallus gallus), in an isolated rearing system $(n=20)$ and a mixed rearing system $(n=20)$, in the city of Patos, Paraíba.

\begin{tabular}{lcccc}
\hline \multicolumn{5}{c}{ Isolated rearing system } \\
\hline \multicolumn{1}{c}{ Louse species } & Number & Mean & \pm SD & P (\%) \\
\hline Menopon gallinae & 63 & $3.15^{\mathrm{ab}}$ & 5.94 & 30.58 \\
Menacanthus stramineus & 7 & $0.35^{\mathrm{bb}}$ & 0.67 & 3.39 \\
Goniodes gigas & 47 & $2.35^{\mathrm{ab}}$ & 1.38 & 22.81 \\
Goniocotes gallinae & 29 & $1.45^{\mathrm{ab}}$ & 0.82 & 14.07 \\
Lipeurus caponis & 60 & $3.0^{\mathrm{ac}}$ & 2.33 & 29.12 \\
\hline \multicolumn{5}{c}{ Mixed rearing system } \\
Menopon gallinae & 43 & $2.15^{\mathrm{a}}$ & 3.28 & 62.31 \\
Menacanthus stramineus & 3 & $0.15^{\mathrm{b}}$ & 0.36 & 4.34 \\
Goniodes gigas & 4 & $0.2^{\mathrm{b}}$ & 4.86 & 5.79 \\
Goniocotes gallinae & 9 & $0.45^{\mathrm{b}}$ & 6.23 & 13.04 \\
Lipeurus caponis & 10 & $0.5^{\mathrm{b}}$ & 6.12 & 14.49 \\
\hline
\end{tabular}

Mean values followed by different letters in the column differed according to Tukey's test, at the probability level of $5 \%(\mathrm{P}<0.05)$ (isolated rearing) and $1 \%(\mathrm{P}<0.01)$ (mixed rearing). and its proliferation is due to the fact that simultaneous rearing of turkeys and hens has been established in the United States. This has also become established in Brazil. It was observed that this louse species was present in both rearing systems, which suggests that it has become adapted to $G$. gallus.

The findings of $M$. stramineus are noteworthy because Tridevi, Saxena and Rawat (1991) reported that parasitism by this louse species causes great irritation in the cloaca region. It was observed in the present study that, as well as from the cloaca, specimens were also collected from the ventral region.

Among the body regions sampled (head, neck, dorsum, venter, cloaca and wings), 206 lice were collected from the chickens reared in the isolated system and 69 from the chicken in the mixed system. In both rearing systems, the regions with greatest infestation were the venter and dorsum, while the regions with least parasitism were the head and cloaca. According to data in the literature, the head is one of the regions least likely to be affected by parasitism due to lice (GABAJ et al., 1993; SANTOS-PREZOTO et al., 2003; GUERRA et al., 2008).

The distribution of the species identified according to host body region, in both rearing systems, are detailed in Table 2.

The species L. caponis seemed to be the one that was best adapted to parasitism in different regions of the body. It was found in all the regions samples in chickens in the isolated rearing system, but the chickens in the mixed system did not present this species in the head and dorsum regions. Guerra et al. (2008) also observed that the species $L$. caponis was collected from all regions of the body, including the head. The other regions presented parasitism by more than one louse species, independent of the rearing system. All of the louse species identified in this study, in both rearing systems, were found in the venter region. $M$. gallinae was the most prevalent species in this region. These data are in agreement with the observations of Ash (1960), with regard to the affirmation that the lice presented defined niches in their hosts.

In relation to the biological development stages of the lice, 1099 eggs, 153 nymphs and 53 adults were obtained in the

Table 2. Prevalence of lice collected from Gallus gallus, in an isolated system ( $\mathrm{n}=20)$ and a mixed system $(\mathrm{n}=20)$, according to regions of the body, in the city of Patos, Paraíba.

\begin{tabular}{|c|c|c|c|c|c|c|}
\hline \multicolumn{7}{|c|}{ Isolated rearing system } \\
\hline \multirow[t]{3}{*}{ Louse species } & \multicolumn{6}{|c|}{ Regions of the body } \\
\hline & Head & Neck & Dorsum & Venter & Cloaca & Wing \\
\hline & N. (\%) & N. (\%) & N. (\%) & N. (\%) & N. (\%) & N. (\%) \\
\hline M. gallinae & $0(0)$ & $6(25)$ & $23(33.82)$ & $27(39.70)$ & $7(38.88)$ & $0(0)$ \\
\hline M. stramineus & $0(0)$ & $0(0)$ & $0(0)$ & $2(2.94)$ & $5(27.77)$ & $0(0)$ \\
\hline G. gigas & $0(0)$ & $7(29.16)$ & $18(26.47)$ & $19(27.94)$ & $3(16.66)$ & $0(0)$ \\
\hline Total & 1 & 24 & 68 & 68 & 18 & 27 \\
\hline \multicolumn{7}{|c|}{ Mixed rearing system } \\
\hline M. gallinae & $0(0)$ & $6(66.66)$ & $17(77.27)$ & $19(55.88)$ & $1(50.0)$ & $0(0)$ \\
\hline M. stramineus & $0(0)$ & $0(0)$ & $0(0)$ & $3(8.82)$ & $0(0)$ & $0(0)$ \\
\hline G. gigas & $0(0)$ & $0(0)$ & $2(9.09)$ & $2(5.88)$ & $0(0)$ & $0(0)$ \\
\hline
\end{tabular}


Table 3. Structure of the louse population collected from Gallus gallus, in an isolated rearing system ( $\mathrm{n}=20)$ and a mixed rearing system $(\mathrm{n}=20)$, in the city of Patos, Paraíba.

\begin{tabular}{|c|c|c|c|c|c|c|c|c|}
\hline \multicolumn{9}{|c|}{ Isolated rearing system } \\
\hline \multirow[t]{3}{*}{ Louse species } & \multicolumn{6}{|c|}{ Biological development stages } & \multirow{2}{*}{\multicolumn{2}{|c|}{ Total }} \\
\hline & \multicolumn{2}{|c|}{ Females } & \multicolumn{2}{|c|}{ Males } & \multicolumn{2}{|c|}{ Nymphs } & & \\
\hline & $\mathbf{N}$. & $(\%)$ & N. & $(\%)$ & N. & $(\%)$ & N. & $(\%)$ \\
\hline M. stramineus & 2 & $(28.57)$ & 0 & $(0)$ & 5 & $(71.42)$ & 7 & $(100)$ \\
\hline G. gigas & 3 & $(6.38)$ & 1 & $(2.12)$ & 43 & $(91.48)$ & 47 & $(100)$ \\
\hline Total & 48 & $(23.30)$ & 5 & $(2.42)$ & 153 & $(74.27)$ & 206 & $(100)$ \\
\hline \multicolumn{9}{|c|}{ Mixed rearing system } \\
\hline M. gallinae & 16 & $(37.20)$ & 0 & $(0)$ & 27 & $(62.79)$ & 43 & $(100)$ \\
\hline M. stramineus & 2 & $(66.66)$ & 0 & $(0)$ & 1 & $(33.33)$ & 3 & (100) \\
\hline G. gigas & 4 & $(100)$ & 0 & $(0)$ & 0 & (0) & 4 & (100) \\
\hline
\end{tabular}

Table 4. Mean intensity and amplitude of infestation with lice collected from Gallus gallus, in an isolated rearing system $(\mathrm{n}=20)$ and a mixed system $(\mathrm{n}=20)$, in the city of Patos, Paraíba.

\begin{tabular}{lccccc}
\hline \multirow{2}{*}{ Lice } & \multicolumn{2}{c}{ Isolated } & & \multicolumn{2}{c}{ Mixed } \\
\cline { 2 - 3 } \cline { 5 - 6 } & MII & AI & MII & AI \\
\hline M. gallinae & $3.15 \pm 5.94^{\mathrm{a}}$ & $1-28$ & & $10.75 \pm 13.20^{\mathrm{b}}$ & $3-9$ \\
M. stramineus & $0.35 \pm 0.67^{\mathrm{a}}$ & $0-2$ & & $0.75 \pm 1.03^{\mathrm{a}}$ & $0-1$ \\
G. gigas & $2.35 \pm 1.38^{\mathrm{a}}$ & $1-5$ & & $1.0 \pm 1.30^{\mathrm{a}}$ & $0-1$ \\
G. gallinae & $1.45 \pm 0.82^{\mathrm{a}}$ & $1-4$ & & $2.25 \pm 2.76^{\mathrm{b}}$ & $1-2$ \\
L. caponis & $3.0 \pm 2.33^{\mathrm{a}}$ & $1-9$ & & $3.07 \pm 3.07^{\mathrm{a}}$ & $1-2$ \\
\hline
\end{tabular}

$\mathrm{MII}=$ mean intensity of infestation; $\mathrm{AI}=$ amplitude of infestation. Mean values followed by different letters in the same line differed according to Tukey's test, at the probability level of $1 \%(\mathrm{P}<0.01)$.

isolated rearing system. In the mixed system, there were 198 eggs, 36 nymphs and 33 adults. Thus the numbers of eggs and nymphs were larger than the numbers of adults, in both systems.

It was observed that the eggs continued to adhere to the plumage of the hens until the nymphs emerged (embryogenesis period), while the nymphs and adults migrated to seek out their preferred habitats (external or internal dewlap; barbules, barbs and radial/filamentous tufts of feathers; lungs; and/or body skin).

The structure of the louse population in the isolated system is summarized in Table 3. It was found that in the isolated system, the prevalence of nymphs was $74.27 \%$, and the prevalence of males was $2.42 \%$. The same distribution was found in the mixed system, i.e. nymphs were seen in greater numbers than other stages.

The data relating to the mean intensity of parasitic infestation (number of lice/number of positive chickens) and the amplitude of infestation are reported in Table 4 . The species $M$. gallinae presented $3.15 \pm 5.94$, with an amplitude from 1 to 28 , in the chickens in the isolated rearing system, while mean intensity in the mixed system was $10.75 \pm 13.20$, with an amplitude from 3 to 9 . This species presented higher values than did the others. There was a statistically significant difference $(\mathrm{P}<0.01)$ in infestation by $M$. gallinae and $G$. gallinae between the chickens kept in the isolated system and those kept in the mixed system, thus showing an association between louse species.

It can be concluded that backyard hens that do not have any sanitary management are predisposed to infestations with lice, and that choosing between an isolated and a mixed rearing system does not provide exemption from parasitism.

\section{References}

ASH, J. S. A study of the Mallophaga of birds with particular reference to their ecology. Ibis, v. 102, n. 1, p. 93-110, 1960.

EMERSON, K. C. Mallophaga (Chewing Lice) occurring of the domestic chicken. Journal of the Kansas Entomological Society, v. 29, n. 2, p. 63-79, 1956.

EMERSON, K. C. Mallophaga (Chewing Lice) occurring on the turkey. Journal of the Kansas Entomological Society, v. 35, n. 1, p. 196-201, 1962.

FERRERO, A. A. et al. Phthiraptera (Arthropoda, Insecta) en Gallus gallus (Galliformes, Phasianidae) en criaderos de áreas urbanas y suburbanas de la ciudad de Bahía Blanca, provincia de Buenos Aires, Argentina. Entomologia y Vectores, v. 11, n. 2, p. 297-303, 2004.

FIGUEIREDO, S. M. et al. Biologia e ecologia de malófagos (Insecta, Phthiraptera) em aves de postura de granjas industriais. Revista Brasileira de Parasitologia Veterinária, v. 2, n. 1, p. 45-51, 1993.

GABAJ, M. M.; BEESLEY, W. N.; AWAN, M. A. Lice of farm animals in Libya. Medical and Veterinary Entomology, v. 7, n. 2, p. 138-140, 1993.

GLESS, E. E.; RAUN, E. S. Effects of chicken body louse infestation on egg production. Journal of Economic Entomology, v. 52, n. 2, p. 358-359, 1959.

GUERRA, R. M. S. N. C. et al. Espécies, Sítios de Localização, Dinâmica e Estrutura de Populaçôes de malófagos em galinhas caipiras (Gallus gallus L.) criadas na ilha de São Luis, MA. Neotropical Entomology, v. 37, n. 3, p. 259-264, 2008. 
INSTITUTO BRASILEIRO DE GEOGRAFIA E ESTATÍSTICA IBGE. Anuário Estatístico. 2002.

OLIVEIRA, C. M. B.; RIBEIRO, V. L. S. Ocorrência de Menachantus cornutus (Mallophaga: Menoponidae) em galinhas do Rio Grande do Sul. Arquivo Brasileiro de Medicina Veterinária e Zootecnia, v. 42, n. 2, p. 121-126, 1990.

OLIVEIRA, H. H.; FERREIRA, I.; SERRA-FREIRE, N. M. Fauna de Mallophaga (Insecta: Aptera) de ectoparasitos em Gallus gallus L. e Columbia livia L. amostrados no Rio de Janeiro. Brasil. Entomologia y Vectores, v. 6, n. 5, p. 509-515, 1999.

PANDA, D. N.; AHLUWALIA, S. S. Affect on the Menacanthus stramineus tropicalis infestation on weight gains in broiler birds. Indian Veterinary Journal, v. 60, n. 2, p. 85-87, 1983.

PINTO, C. et al. Ocorrência de Malófagos em galinhas caipiras e sua relação com o padrão de coloração da plumagem. Entomologia y Vectores, v. 8, n. 3, p. 295-301, 2001.

PINTO, C. Zooparasitos de interesse médico e veterinário. Pimenta de Mello Cia, 1938. 369 p.
SANTOS-PREZOTO, H. H. et al. Sítios de localização de ectoparasitos em Gallus gallus Linnaeus, 1758. Revista Brasileira de Zoociências, v. 5, n. 1, p. 129-135, 2003.

SILVA, S. B. Dinâmica da fauna ectoparasitária (Ischnocera, Amblycera e Acari) em galinhas domésticas (Gallus gallus) de criaçóes rústicas no município de Patos, Paraíba, Estudo preliminares. 2002. 68 f. Dissertação (Mestrado)-Universidade Federal Rural do Rio de Janeiro, Rio de Janeiro.

SILVEIRA NETO, S. S. Manual de ecologia dos insetos. São Paulo: Agronomia Ceres, 1976. 419 p.

TRIDEVI, M. C.; SAXENA, A. K.; RAWAT, B. S. Incidence of Mallophaga on poultry in Dehradun (India). Angewandte Parasitologie, v. 33, n. 2, p. 69-78, 1991.

TUFF, D. W. A key to the lice of man and domestic animals. Texas Journal Science, v. 28, n. 1-4, p. 145-158, 1977.

UGOCHUKWU, E. I.; OMIJE, J. S. Ectoparasitic fauna of poultry in Nsukka, Nigéria. International Journal of Zoonoses, v. 13, n. 2, p. 93-97, 1986. 